\title{
A critical analysis of the 2014 CUA guidelines for erectile dysfunction: Is there more that can be done?
}

\author{
Jason R. Kovac, MD, PhD, FRCSC \\ Urology of Indiana, Male Reproductive Endocrinology and Surgery, Carmel, IN
}

See related article on page 23.

Cite as: Can Urol Assoc J 2015;9(1-2):30-1. hittp://dx.doi.org/10.5489/cuaj.2731 Published online February 5, 2015.

$\mathrm{T}$ his month's edition of the CUAJ presents a needed update to the guidelines for the treatment of erectile dysfunction (ED). The authors go to great lengths to ensure a thorough and appropriate review of the diagnosis, testing options (both laboratory and specialized), and treatment possibilities available.

As mentioned in the guidelines, ${ }^{1}$ primary care physicians perform most of the initial ED diagnosis and treatment in both the United States and Canada. It is therefore important for frontline healthcare providers to impart the knowledge that lifestyle modifications improve ED outcomes. While treatment with phosphodiesterase type- 5 inhibitors (PDE5i) evokes rapid results, the long-term benefits of a healthy lifestyle should also be encouraged upon initial presentation as an adjunct to PDE5i treatment.

Indeed, cross-sectional analyses of data from the U.S. Health Professionals prospective cohort study (31 742 men, aged 53-90 years), found physical activity was associated with a lower relative risk for ED (RR 0.7) and obesity associated with a higher relative risk for ED (RR 1.3). ${ }^{2}$ Epidemiological studies have also highlighted the relationships between smoking and the development of $\mathrm{ED},{ }^{3}$ while direct physiological evidence linking cigarette smoke to alterations in the nitric oxide signal transduction pathway is well-described. ${ }^{4}$ By highlighting these areas in the initial treatment portion of the algorithm, long-term outcomes might be improved.

An understanding of the evaluation and management of cardiovascular disease (CVD) risk in men with vasculogenic ED is also important. ${ }^{5}$ The Princeton III consensus recommendations suggest that all men $>30$ years with ED should be considered at increased risk for CVD. As such, evaluations, including a baseline physical examination, fasting plasma glucose level, serum creatinine and plasma lipid levels, should be undertaken. ${ }^{5}$ The Princeton III recommendations also suggest that testosterone levels should be "routinely measured" in all men who fail PDE5i therapy. More invasive evaluations could be performed in a subset of men via physiological stress testing for ischemia or anatomical analysis via coronary computed tomographic angiography, coronary artery calcium scoring or assessment of carotid intima-media thickness. ${ }^{5,6}$

The new Canadian guidelines do well to include optional hormone testing via examination for occult diabetes, with serum $\mathrm{HbA} 1 \mathrm{c}$ specifically mentioned. ${ }^{1}$ The precursor condition, metabolic syndrome (MetS), should also have a high index of suspicion. Composed of a constellation of risk factors (waist circumference, high triglycerides, low highdensity lipoprotein cholesterol, high blood pressure and insulin resistance), MetS affects $20 \%$ to $30 \%$ of the adult population and is related to an all-cause mortality of about $7 \% .^{7}$ Implicit in the etiology of MetS is hypogonadism, with research suggesting that men with MetS benefit from testosterone supplementation therapy (TST). ${ }^{8}$ As such, screening for diabetes mellitus in men with ED could go hand-in-hand with MetS and hypogonadism.

The role of testosterone in erectile function is well-known and it affects nearly every facet of the erectile pathway from the central nervous system to smooth muscle function to the fibro-elastic properties of the corpus cavernosum. ${ }^{9}$ TST also increases the number of circulating endothelial progenitor cells responsible for endothelial repair, ${ }^{10}$ suggesting a link between erectile function and testosterone. Other hormones also need to be considered as evidenced by recent work highlighting the importance of estradiol on libido in men on TST. ${ }^{11}$

Salvaging men who fail PDE5i monotherapy with TST is controversial. ${ }^{9}$ It is logical to assume that in men with 
low testosterone, PDE5i do not address issues with libido and other symptomatic manifestations of hypogonadism (i.e., fatigue) that affect erectile function. Furthermore, in the TADTEST trial, Buvat and colleagues ${ }^{12}$ identified that PDE5i efficacy was suboptimal below a serum testosterone threshold of $300 \mathrm{ng} / \mathrm{dL}$. In this subset of patients, PDE5i non-responders experienced improved erectile function after normalization of serum testosterone levels.

Another clinical situation that needs to be considered is ED in men with prostate cancer - either on active surveillance or post-therapy. ${ }^{13}$ While most assuredly an indication for specialist referral, the concept of prostate cancer being an absolute contraindication to TST is currently being challenged. ${ }^{14}$ Indeed, most of the current evidence suggests that it is reasonable to offer TST to a selected group of individuals with a history of prostate cancer. ${ }^{14,15}$

In summary, the current guidelines offer an excellent synopsis for the management of ED patients. Subtle intricacies and variable treatment options exist beyond the scope of the guidelines. These strategies should be limited to those practitioners comfortable with their management. Lifestyle modifications should always be promoted as first-line therapy. The long-term benefits to the screening and treatment of CVD, diabetes mellitus and MetS may yield improvements in ED rates along with increased overall survival. The treatment of ED in men with prostate cancer should be referred to a subspecialist.

Regardless of a patient's situation, the most important aspect of treating ED is initiating the conversation. The message to men afflicted with ED should be that regardless of their individual situation, they are not alone - there is always hope for regaining sexual function.

Competing interests: Dr. Kovac declares no competing financial or personal interests.

\section{References}

1. Bella AJ, Benard F, Brock GB, et al. 2015 Canadian urological Association Guidelines for Erectile Dysfunction. Can Urol Assoc J 2015;9:23-9. http://dx.doi.org/10.5489/cuaj.2699

2. Bacon CG, Mittleman MA, Kawachi I, et al. Sexual function in men older than 50 years of age: results from the health professionals follow-up study. Ann Intern Med 2003;139:161-8. http://dx.doi. org/10.7326/0003-4819-139-3-200308050-00005

3. Bacon CG, Mittleman MA, Kawachi I, et al. A prospective study of risk factors for erectile dysfunction. J Urol 2006;176:217-21. http://dx.doi.org/10.1016/S0022-5347(06)00589-1

4. Kovac JR, Labbate C, Ramasamy R, et al. Effects of cigarette smoking on erectile dysfunction. Andrologia 2014.Epub 2014 Dec 29. http://dx.doi.org/10.1111/and.12393

5. Nehra A, Jackson G, Miner M, et al. The Princeton III Consensus recommendations for the management of erectile dysfunction and cardiovascular disease. Mayo Clin Proceed 2012;87:766-78. http://dx.doi. org/10.1016/i.mayocp.2012.06.015

6. Naghavi $M$, Falk E, Hecht $H S$, et al. From vulnerable plaque to vulnerable patient-Part III: Executive summary of the Screening for Heart Attack Prevention and Education (SHAPE) Task Force report. Am J Cardiol 2006;98:2H-15H. http://dx.doi.org/10.1016/i.amicard.2006.03.002

7. Ford ES. Risks for all-cause mortality, cardiovascular disease, and diabetes associated with the metabolic syndrome: A summary of the evidence. Diabet Care 2005;28:1769-78. http://dx.doi.org/10.2337/ diacare.28.7.1769

8. Kovac J, Pastuszak AW, Lamb DJ, et al. Testosterone supplementation therapy in the treatment of patients with metabolic syndrome. Postgrad Med 2014;126:149-56. http://dx.doi.org/10.3810/ pgm.2014.11.2843

9. Isidori AM, Buvat J, Corona G, et al. A critical analysis of the role of testosterone in erectile function: From pathophysiology to treatment-a systematic review. Eur Urol 2014;65:99-112. http://dx.doi. org/10.1016/i.eururo.2013.08.048

10. Liao $\mathrm{CH}, \mathrm{Wu}$ YN, Lin FY, et al. Testosterone replacement therapy can increase circulating endothelial progenitor cell number in men with late onset hypogonadism. Andrology 2013;1:563-9. http://dx.doi. org/10.1111/i.2047-2927.2013.00086.x

11. Ramasamy R, Scovell JM, Kovac JR, Lipshultz LI. Elevated serum estradio is associated with higher libido in men on testosterone supplementation therapy. Eur Urol 2014;65:1224-5. http://dx.doi.org/10.1016/i. eururo.2014.01.012

12. Buvat J, Montorsi F, Maggi M, et al. Hypogonadal men nonresponders to the PDE5 inhibitor tadalafil benefit from normalization of testosterone levels with a $1 \%$ hydroalcoholic testosterone gel in the treatment of erectile dysfunction (TADTEST study). J Sex Med 2011;8:284-93. http://dx.doi.org/10.1111/i.17436109.2010.01956.x

13. Kovac JR, Pan MM, Lipshultz LI, et al. Current state of practice regarding testosterone supplementation therapy in men with prostate cancer. Steroids 2014;89:27-32. http://dx.doi.org/10.1016/i. steroids.2014.07.004

14. Klap J, Schmid M, Loughlin KR. The relationship between total testosterone levels and prostate cancer: A review of the continuing controversy. J Urol 2015;193:403-14. http://dx.doi.org/10.1016/i. juro.2014.07.123. Epub 2014 Sep 28.

15. Khera $M$, Crawford D, Morales $A$, et al. A new era of testosterone and prostate cancer: from physiology to clinical implications. Eur Urol 2014;65:115-23. http://dx.doi.org/10.1016/i.eururo.2013.08.015

Correspondence: Dr. Jason R. Kovac, Urology of Indiana, 12188-A North Meridian Street, Suite 200, Carmel, IN 46032; ikovac@urologyin.com 